市北区北 9 条西 9 丁目 北海道大学農学部植物学教室 内 Tel 011-711-2111(内)2473四方)

昭和54年植物感染機作・病理化学談話会の開催

テーマ: 植物感染における制御機構

日 時：昭和 54 年 7 月 14 日（土）午後 2 時〜 16 日（月）

午後 1 時

場 所：長野県諏訪郡下諏訪町 山王閣

Tel. 02662- 7-9113

話題とその提供者:

特別講演

1. 植物汇招ける電気生理学一その現状と展望 岡本尚 (名大理)

2. 植物感染における過敏感反応をめぐって 冨山宏平（名大農）

一般講演

I 病原菌の形態形成制御機構

3. 感染に打ける菌の形態形成の意義 伊藤征男 （農技研）

4. 病原菌の形態形成における生理活性物質 服部 宏之 (名大農)

II 感染過程の形態的アプローチ

5. 感染初期に抢汀る微量元素の役割 久能 均 (三重大農)

6. 吸器周辺の構造と機能 高橋賢司（農技研）

7. 感染反応の蛍光顕微鏡に上る細胞化学的研究 豊田秀吉（京大農）

III 感染組織化㧍ける抗菌性物質

8. 木本植物に扔ける抗菌性物質の生成 白田 昭 （農技研）

9. イネ科植物に打ける抗菌性物質 真山滋志 （香川大農）

10. イネに含まれる抗白葉枯病菌物質 堀野 修 (北陸農試)

IV 感染組織に打ける抗菌性物質の生合成之代謝

11.ファイトアレキシンの蓄積機構と病理学的動態 吉川正明（京都府大農）

12. ファイトアレキシンの生成・蓄積機構 大羽和 子 (名大農)

$\mathrm{V}$ 系状菌感染反応の調節機構

13. 菌体成分による感染反応の調節 白石友紀（岡 大農）

14. 病・傷害リグニン形成制御機構 松本 勲（愛 媛大農)

15. 宿主特異的毒素による感染反応の調節 尾谷 浩 (鳥取大農)

16. 菌体成分之感染反応の調節機構

\section{道家紀志 (名大農)}

VI ウイルス感染反応の制御

17. ウイルス感染阻害物質の性質とその作用機構 谷口武(名大農)

18. ウイルス感染之局部病斑形成 大橋祐子 (ウイルス研)

19. ウイルス感染に抢ける宿主反応 加藤 盛 (東北大農)

参加申込は 5 月 31 日までに，名古屋市千種区不老町 （干 464）名古屋大学農学部道家紀志宛化打願いしま す。な扮宿泊料は 2 泊で 10,000 月の予定ですが，申込 者には日程, 宿泊などの案内を追ってお送りします。

（予稿集のみの申込を受付けます。）

\section{Mycoplasma Techniques Course のお知らせ}

日時 1979 年 9 月 $3-21$ 日

場所 University of Bordeaux II, フランス詳細 については下記にお問い合わせ下さい。

International Organization for Mycoplasmology, c/o Dr. J. M. BOVE, Laboratorie de Biologie Cellulaire et Meléculaire, Centre de Recherches de Bordeaux (INRA), 33140 PONT DE LA MA. YE, FRANCE.

会員逝去

$$
\text { 田中伊之助 应 }
$$

\section{第10回 植物細菌病談話会の開催}

日時 昭和 54 年 6 月 11 日（月曜日） $10.00 \sim 17.00$

場所 札棍市豊平区羊ケ丘 1 番地

北海道農業試験場

詳細は追って発表予定

連絡先 T061-01 札昽市豊平区羊ケ丘 1 番地 北海 道農業試験場 病害第 1 研究室 柳田騏策

Tel. 011-851-9141 内277

\section{学会報第44巻第 4 巻正誤表}

筒所

466 頁 20 行目

468 頁 1 行目

誤

\begin{tabular}{|c|c|}
\hline " 11 行目 & {$[1(2 / 5]$} \\
\hline 12行日 & {$[1(1 / 5)]$} \\
\hline
\end{tabular}

正

472頁 引用文献 1 ……論文, ………論文.

473頁 Fig.17説明 3 行目 Wilted wilted

513頁 Fig. 2 グラフ縦軸の説明

左の図 $\mathrm{mg}$ Protein $/ 15 \mathrm{ml}$ culture mg RNA $/ 15 \mathrm{ml}$ culture 右の図 $\mathrm{mg}$ Protein $/ 15 \mathrm{ml}$ culture $\mu \mathrm{g}$ RNA/15ml culture

521頁 Table 1-2. DL-glycine glycine 527頁 Table 1. 4 行目 $0.66 \quad 0.066$ 